\title{
OCCUPATIONAL HEALTH AND SAFETY SPECIALIST IN CROATIAN AND PORTUGUESE LEGISLATION
}

\author{
Domagoj Šantek \\ Professional Specialist Engineer of Safety and Protection, graduate student at Polytechnic of Rijeka, \\ Vukovarska 58, 51000 Rijeka, Croatia; e-mail: dsantek5@gmail.com
}

Sandra Debeljak

PhD, Lecturer, Polytechnic of Rijeka, Vukovarska 58, 51000 Rijeka, Croatia; e-mail: sandra.debeljak@veleri.hr

\section{Rui Isidoro}

PhD, Adjunct Professor, Polytechnic Institute of Beja, Rua Pedro Soares, Campus do Instituto Politécnico de Beja, 7800-295 Beja, Portugal; e-mail: rui.isidoro@ipbeja.pt

\begin{abstract}
The domain of occupational safety and health at work is put for regulation through directives by founding agreements. This means that the institutions of the European Union prescribe minimum standards of safety and health at work through directives and Member States need to accomplish goals that a particular directive pursues. At the same time, this means that each Member State can also set stricter standards than the ones prescribed through directives and for this reason some differences in regulations of individual Member States can be noticed. In this paper, authors focus on the role of occupational safety specialist and the manner in which the Republic of Croatia and the Portuguese Republic, in their legislation, prescribe obligations of the employer in terms of contracting the performance of occupational health and safety tasks with an occupational safety specialist or an external service. Authors furthermore examine required conditions which occupational safety specialist must meet to perform those tasks. Apart from outlining the Croatian and Portuguese legislation, authors also present and define fundamental similarities and differences in the regulations within this domain of security legislation.
\end{abstract}

Key words: Directive 89/391/EEC, occupational health and safety specialist, Croatian legislation, Portuguese legislation 


\section{INTRODUCTION}

As binding agreements between the Member States, EU agreements stipulate, through directives, that competent European Union institutions make minimum requirements to encourage improvements, particularly in the domain of work environment, in order to ensure a higher level of safety and health protection of workers at work. It can therefore be stated that the Council Directive of 12 June 1989 on the introduction of measures for encouraging improvements in safety and health protection of workers at work $(89 / 391 / \mathrm{EEC})^{1}$ is one of the most significant documents that introduces minimum standards in this domain in all Member States, at the same time not interfering with the existence and application of higher and stricter standards that Member States might have and/or develop.

One of the domains in which the European Union supports and supplements activities of Member States refers to the improvement of work environment in particular, for the purpose of protection of health and safety of workers. With that purpose, the European Parliament and the Council may adopt measures in order to support cooperation between Member States through different initiatives with the aim of improving knowledge, exchange of data and best practices, promoting innovative approaches and evaluating experiences. In addition to these activities, the European Parliament and the Council may, by means of directives, adopt minimum requirements for encouraging improvements in safety and health at work (Article 153 of the UEU) ${ }^{2}$. Therefore, in addition to the aforementioned Directive 89/391/EEC, some thirty individual directives were adopted for the domain of safety and health of workers at work and related to work (Šokčević, 2014).

Directive 89/391/EEC realizes its objective of introducing measures to encourage improvements in safety and health of workers at work, containing in its provisions general principles concerning prevention of occupational risks, protection of safety and health, elimination of risk and accident factors, informing and consultation in accordance with national laws and / or practices and training of workers and their representatives, as well as general guidelines for the implementation of said principles (Article 1, paragraphs 1 to 2 of Directive 89/391/EEC).

EU and national legislations that set good standards of protection present the first step towards achieving quality of health and safety protection in the workplace. Clear and effective rules are a significant basis for further improvement of occupational safety and health. Employers should have a clear understanding of minimum requirements set by relevant regulations so that they can develop the best possible safety culture, primarily with the assistance of occupational health specialists. In this regard, many authors emphasize the importance of effective cooperation of all participants in implementation of occupational safety and pay particular attention to the occupational safety specialist and his education and training.

Research shows that occupational safety specialists themselves point out the lack of knowledge in certain areas as well as the lack of opportunities to fulfil their needs in terms of continuous training. With regard to their advisory role for the employer, occupational safety specialists must

${ }^{1}$ OJ L 183, 29. 6. 1989; hereinafter referred to as Directive 89/391/EEC or the Directive.

${ }^{2}$ Treaty on European Union (consolidated version), OJ C 202, 7.6.2016., hereinafter referred: UEU. 
follow dynamic changes in the field of work and, with their knowledge and skills, assist employers in securing a safe and healthy workplace (Krišto, Batak, 2012). It is the task of occupational safety specialists to educate and simultaneously motivate workers towards practising healthy ways of work. At the same time, they should develop an appropriate culture of protection and, additionally, continuously work on their education. In this regard, it is a calling with a universal role that connects all forms of knowledge in an understandable way and passes it on to competent persons at the company - therefore, motivation for advancement in the profession and increase of knowledge for such specialists should not be put into question (Ninčević, Pavlič, 2016). There is an increasing need for skilled OSH professionals in the world where working conditions for the majority of workers do not meet the minimum standards and guidelines. Training programs in occupational safety and health are fundamental to prevention in the workplace (Bosio et al., 2018, 331).

In the field of occupational safety and health, which is subject to constant influences and changes, it is important to preserve acquired rights in the legislation in general, and in particular in labour legislation and regulation regarding safety at work. This is in accordance with the universal and regional sources of law (such as Directive 89/391/EEC), as well as with basic national legal acts of individual countries. Occupational health professionals, as experts in their field, must play a key role here (Učur, 2013). Due to the shared responsibility of all participants for occupational safety and health, strategies in this field must focus on consistent implementation of regulations that define the area, as well as on measures that will encourage employers to ensure better working conditions than the minimum ones required by regulations (Vedenik, 2011). In order to put into practice the legislation of occupational safety and health, cooperation between all participants in this process -such as the employer, employees, occupational safety services and selected occupational health specialists - is essential (Sarić et al. 2019).

The role and importance of knowing and understanding applicable legal rules in a particular area of occupational safety and health is an extremely important first step in the effective protection of occupational health for all participants, and in particular for employers with the highest burden of obligations and responsibilities in this area. In this paper, the authors focus on the part of Directive $89 / 391 / \mathrm{EEC}$ provisions which regulate the issue of determining one or more workers to carry out occupational risk protection and prevention activities on behalf of the employer, possible engagement of professional external services or persons and the Member States' obligation to determine abilities and skills required for such appointed workers or external services so that they can carry out activities related to protection and prevention of occupational risks for which they are appointed or contracted within the undertaking or establishment. Authors present how these issues and definitions of the Directive are regulated and applied in Croatian and Portuguese legislation and show basic differences in legislation of these two EU Member States.

\section{METHODOLOGY}

In order to achieve the objective of the article, a secondary survey was conducted, one that included an analysis of available scientific and professional domestic and international literature, as well as an analysis of valid legal rules within the framework of EU law and under Croatian and Portuguese legislations. Research of available scientific and professional literature was done 
primarily by searching the Internet, but also using relevant literature from the libraries of the authors' native institutions. Relevant legal documents used in the article were collected from the official gazettes of Croatia and Portugal (https://www.nn.hr/, https://dre.pt/) and the official website of EU legislation (https://eur-lex.europa.eu/), as well as from other relevant data sources, such as websites of the relevant ministries and other. Collected data was processed by analysis, synthesis, compilation and comparative method.

\section{DIRECTIVE 89/391/EEC, CROATIAN AND PORTUGUESE LEGISLATION IN RELATION TO OCCUPATIONAL HEALTH AND SAFETY SPECIALIST}

\section{1 Protection and prevention services according to Directive 89/391/EEC}

Article 5 (1) of the Directive, containing general provisions, states that the employer's duty is to ensure the safety and health of workers in all aspects related to their work. Consequently, in Article 7 (Protective and preventive services), the employer specifies one or more workers to carry out activities related to the protection and prevention of occupational risks to the undertaking or establishment (Article 7 (1) Directive 89/391/EEC). However, if such protective and preventive measures cannot be organized due to the lack of competent personnel, the employer is obliged to enlist competent external services or persons (Article 7, paragraph 3 of Directive 89/391/EEC).

Appointed workers must have the necessary abilities and resources, while consulted external services or persons must also have required abilities and appropriate personal and professional resources. The number of appointed workers and external services or persons must be sufficient to organize protection and prevention measures depending on the size of the undertaking, dangers to which workers are exposed and their disposition in the undertaking or the establishment. Member States define necessary abilities and skills of designated workers and external services or persons and may determine their sufficient number (Article 7, paragraphs 5 and 8 of Directive 89/391/EEC).

Depending on the nature of the activity and the size of the undertaking,Member States may determine types of undertakings in which the employer, provided he is competent, assumes responsibility for carrying out these measures related to protection and prevention of occupational risks for the undertaking or establishment (Article 7 (7) of Directive 89/391/EEC), by which the possibility that the employer himself carries out occupational safety work if he is competent is prescribed.

In Case C-441/01, the Court of the European Union points out that Article 7 of the Directive places priority on the employer's obligations. Priority is given to the obligation of the employer to designate one or more workers to implement the protection and prevention of occupational risks, and only (indirectly) to engage external assistance in cases, when protection and prevention of occupational risks cannot be organized due to the lack of competent workers. The Court also explains objectives of the Directive relating to Article 7 in other cases, such as in Case C-49/00, C-428/04, and others. The basic principle of $\mathrm{EU}$ law is that there must always be a worker in the undertaking with a previously stated engagement in occupational safety works. More specifically, that can be an appointed worker, that is, workers, the employer himself (within certain frameworks and with adequate competencies), 
and, in cases in which such requirements are not met, an external legal or natural person (Šokčević, 2014).

The aforementioned persons should not be confused with the concept of workers' representatives with special responsibility for safety and health of workers referred to in Article 3 (1) (c) of the Directive. This notion refers to any person who is elected, chosen or designated in accordance with national laws and/or practices to represent workers in case of problems arising in the area of safety and health at work.

\subsection{Legislation of the Republic of Croatia}

The Occupational Health and Safety Act is the basic act regulating health and safety at work in The Republic of Croatia (OG No. 71/14, 118/14, 154/14, 94/18 and 96/18). ${ }^{3}$ It regulates issues and relations between numerous subjects in occupational safety. The most important persons in this regard are, of course, the employer and the worker, but their rights, obligations, and responsibilities function also in relation to other persons, such as the employer's authorized representative, commissioner for occupational safety, specialist in occupational medicine, occupational health and safety specialist, the authorized person, and others. Each of these subjects has rights, obligations and responsibilities not only under the Occupational Safety Act but also according to standards of numerous other heteronomous and autonomous regulations in the field of occupational safety. Certain issues relevant to the work of some of these entities are regulated by subordinate legal acts (Učur, 2015).

In Article 3, The Occupational Health and Safety Act defines, inter alia, notions of authorized officer, authorized person, commissioner for occupational safety and occupational health and safety specialist. According to the Act, the authorized officer is an employee to whom the employer gives authority to implement occupational safety and health protection, notwithstanding other contracted work (Article 3, paragraph 1, item 12 of The Occupational Health and Safety Act).

The employer may delegate implementation of occupational health and safety in writing to his authorized officer within his scope of work. Legal provisions state authorizations of the authorized officer on the basis of which he is authorized not to allow an employee to work if he is not trained to work in a safe manner or to work without the supervision of a trained employee; not to allow employees to perform works with special working conditions if they do not meet the requirements for that work; prohibit particularly vulnerable groups of employees to work in operations which could adversely affect them; exclude from use defective work equipment; keep designated records in collaboration with the specialist for occupational health and safety; supervise and even prohibit the work of workers; ensure the required number of employees trained for evacuation, rescue and first aid; ensure the ban on alcohol use during work hours and other (Articles 23-24 of the The Occupational Health and Safety Act; Učur, 2015). Commissioner for occupational safety is an employee elected to represent, in accordance with The Occupational Health and Safety Act, the interests of employees in the domain of occupational health and safety (Article 3, paragraph 1, item 17 of The Occupational Health and Safety Act). He is obliged to protect interests of employees in the domain of occupational health and safety and monitor implementation of rules, measures,

${ }^{3}$ Hereinafter referred: The Occupational Health and Safety Act or Act. 
procedures and activities relating to occupational health and safety (Article 71, paragraph 1 of The Occupational Health and Safety Act). It is a person referred to in Article 3 (1) (c) of Directive $89 / 391 /$ EEC. Occupational health and safety specialist is an employee appointed by the employer to perform tasks of occupational health and safety who meets requirements prescribed for performing such tasks, and an authorized person is a legal or natural person authorized to perform activities of occupational safety and health protection by the competent ministry of labor (Article 3, paragraphs 1, 13 and 29 of The Occupational Health and Safety Act).

The following pages discuss contracting an occupational health and safety specialist, and exceptionally an authorized person, with occupational health and safety tasks, occupational health and safety tasks, conditions that must be met by occupational health and safety specialists and the manner of their training, as well as the necessary number of these persons with individual employers.

\section{2. 1 Performing of occupational health and safety tasks}

Article 20 of The Occupational Health and Safety Act of the Republic of Croatia, in accordance with Article 7 of the Directive, stipulates conditions under which the employer contracts one or more persons with carrying out of occupational safety tasks, i. e an occupational health and safety specialist or an external service. Required qualifications and the number of occupational health and safety specialists, manner and conditions for carrying out occupational safety tasks with the employer depending on the risks, activity and the number of employees, are prescribed in Ordinance on Performance of Occupational Health and Safety Tasks (OG No. 112/14, 43/15, $72 / 15$ and $140 / 15)^{4}$ and Ordinance on Occupational Health and Safety Training and Professional Examination (OG No. 112/14). ${ }^{5}$

In Occupational Health and Safety Act, contracting the performance of occupational health and safety tasks depends on the number of employees in the company:

- Up to and including 49 employees: the employer may carry out the tasks referred to in paragraph 1 of this Article himself if he meets the prescribed requirements or can contract the performance of these tasks by virtue of an employment contract with an occupational health and safety specialist; in accordance with subordinate regulation, this must be at least one occupational health and safety specialist, I degree (Article 20, paragraph 2 of the Act, Article 6 of the Ordinance on performance of Occupational Health and Safety Tasks)

- from 50 up to, and including, 249 employees: the employer is obliged to contract the performance of an occupational health and safety specialist, II degree ${ }^{6}$, with the tasks by virtue of an employment contract (Article 20, paragraph 3 of the Act, Article 7, paragraph 1 of the Ordinance on Performance of Occupational Health and Safety Tasks)

\footnotetext{
${ }^{4}$ Hereinafter referred: Ordinance on performing of occupational health and safety tasks.

${ }^{5}$ Hereinafter referred: Ordinance on Occupational Health and Safety Training and Professional Examination.

${ }^{6}$ Except where at least $80 \%$ of employees carry out only low-risk jobs; in that case it is sufficient to hire an occupational health and safety specialist, I degree (Section 7, paragraph 2 of the Ordinance on Performance of Occupational Health and Safety Tasks).
} 
- 250 or more employees: the employer is obliged to contract the performance of the tasks with one or more occupational health and safety specialists in accordance with subordinate regulations; at least one occupational health and safety specialists, II degree, and one occupational health and safety specialist, I degree, and at least one occupational health and safety specialist, II degree, for up to every following 500 workers $^{7}$ (Article 20, paragraph 4 of the Act, Article 8, paragraph 1 of the Ordinance on Performance of Occupational Health and Safety Tasks).

Exceptionally, the employer may contract the performance of the tasks of occupational health and safety with an authorized person. This is only possible when there is an objective and legitimate reason for the employee not being able to perform occupational health and safety tasks by himself, or when he cannot contract the performance of these tasks by working contract with the occupational health and safety specialist (Article 20, paragraph 5 of the Act). ${ }^{8}$ In such case, an authorized person has to appoint, in writing, one or more occupational health and safety specialists to perform occupational health and safety tasks for that employer (Article 20, paragraph 6 of the

${ }^{7}$ Except where at least $80 \%$ of employees carry out only low-risk jobs, and at least one occupational health and safety specialist, II degree, performs occupational health and safety tasks, and for every following 2,000 workers, at least one more occupational health and safety specialist, II degree, performs such tasks (Article 8, paragraph 2 of the Ordinance on Performance of Occupational Health and Safety Tasks).

${ }^{8}$ One of the following reasons is considered to be an objective and justifiable reason for contracting out an occupational health and safety tasks with an authorized person:

- commencement of the business activity, for a period of maximum of 3 months from the date when the employer's obligation to apply the regulations on occupational health and safety begins;

- unforeseeable reasons (death, dismissal, etc.) for which the employer temporarily loses the occupational health and safety specialist, for a maximum of 3 months from the day when these reasons have occurred;

- if an employer who employs up to and including 249 workers has no employees with required professional qualifications for taking a professional exam for occupational health and safety specialists among the workers who are employed for an indefinite period;

- if an employer employs additional workers, whether seasonal or temporary, or uses the workers assigned to work temporarily, which increases the requirements for performing occupational health and safety tasks in accordance with prescribed conditions, where such employment does not last for more than 6 month; a period shorter than two months is not considered to be an interruption of the said period;

- When an employer employing up to and including 49 workers cannot arrange performing of occupational health and safety tasks because the employer does not have a worker who fulfils the conditions for carrying out these jobs (Article 5, paragraph 2 of the Ordinance on Performance of Occupational Health and Safety Tasks).

It should be emphasized that objective and justified reasons are expressly provided by the provisions of the Ordinance on Performance of Occupational Health and Safety Tasks. At the time of adoption of the Occupational Health and Safety Act in 2014 and this Ordinance, a more detailed definition of what the considered objective and justified reasons for contracting of performing occupational health and safety tasks at work with an authorized person are was completely missing. The first four reasons are stated in the Addendum to the 2015 Ordinance (OG No. 43/15), while additional addendum of the mentioned Ordinance from the same year (OG No. 72/15) adds the fifth reason, primarily because of the pressure of smaller employers who were, with the new Act and subordinate regulations of 2014, faced with the obligation to hire occupational health and safety specialists even in cases of having only one employee employed on small-risk works. By the aforementioned amendment and by fulfilling prescribed conditions, they are able to arrange the performance of occupational health and safety tasks with an external service authorized for such tasks, the same as before the time of adoption of new regulations. At the same time, they can use other objective and justified reasons that correspond to their specific situation and function within some of the prescribed frameworks. 
Act). An occupational health and safety specialist, appointed by an authorized person to perform occupational safety tasks, is obliged to perform these tasks at the workplace of the employer and the authorized person and the employer are obliged to keep records and submit them to the Institute for the Advancement of Safety at Work (Article 5, paragraph 3 of the Ordinance on Performance of Occupational Health and Safety Tasks).

\subsubsection{Conditions for an occupational health and safety specialist}

Occupational health and safety tasks for the employer can be performed by an occupational health and safety specialist who meets the requirements stated by the Ordinance on Performance of Occupational Health and Safety Tasks (Article 2, paragraph 1 of the Ordinance on Performance of Occupational Health and Safety Tasks).

Occupational health and safety specialist who performs occupational health and safety tasks for the employer or an employer who performs those tasks himself must be educated in the area of technical, bio-technical or natural sciences or in the area corresponding to the employer's activity. Depending on the number of workers and business activities of the employer, the occupational health and safety specialist can perform occupational health and safety tasks for the employer as an occupational health and safety specialist, I or II degree (Article 2, paragraphs 2 and 3 of the Ordinance on Performance of Occupational Health and Safety Tasks).

An occupational health and safety specialist, I degree, is a person who has completed a high school level of education and who has successfully passed the general part of professional occupational health and safety exam, or has completed a high school level of education and has a recognized status as an occupational health and safety specialist, or possesses the certificate of occupational health and safety at work approved by the competent education authority. An occupational health and safety specialist, II degree, is a person who has at least obtained an undergraduate degree (bachelor's degree) and has passed both the general and special parts of the professional examination for an occupational health and safety specialist or has the recognized status of the occupational health and safety specialist (Article 3 of the Ordinance on Performance of Occupational Health and Safety Tasks).

Regarding occupational health and safety specialists who are employed by an authorized person, the Ordinance on Authorizations for Occupational Health and Safety Tasks (OG No.50/19) ${ }^{9}$ prescribes conditions that define prescription of a type and number of occupational health and safety specialists with an authorized person who must be a full-time employee (Čizmar, 2017). Occupational health and safety tasks for which the authorized person is authorized are occupational health and safety tasks with an employer, occupational health and safety training (training of workers to work safely and training of employers, authorized officer and commissioner of occupational safety), drafting risk assessment, checking work equipment, and testing physical, chemical and biological factors in the work environment (Article 2, paragraph 1 of the Ordinance on Authorizations for Occupational Health and Safety Tasks). All professional conditions to be met by the employer, legal or natural person, in order to obtain authorization for some or all of

${ }^{9}$ Hereinafter referred: Ordinance on Authorizations for Occupational Health and Safety Tasks. 
these types of tasks, are prescribed by articles 3 to 7 of this Ordinance. Depending on the type of occupational health and safety tasks for which authorization is issued, a minimum of occupational health and safety specialists and those who have completed a field of study in relevant fields such as mechanical engineering, physics, electrical engineering, chemistry, and others, a certain number of years of work experience in occupational health and safety, as well as other appropriate conditions (Articles 3 to 7 of the Ordinance on Authorizations for Occupational Health and Safety Tasks) are required.

In contrast to the Ordinance on Authorizations for Occupational Health and Safety Tasks, which explicitly stipulates the obligation to employ a certain number of occupational health and safety specialists with authorized person employed full-time ${ }^{10}$, when it comes to occupational health and safety specialists employed by the employer to perform occupational health and safety tasks, they can, but do not have to, be employed full-time, because such condition is not prescribed. However, in this case, it is necessary that conditions set out in article 22, paragraph 1 of The Occupational Health and Safety Act, particularly those regarding the obligation of the employer to enable the occupational health and safety specialist to meet his obligations and to provide the necessary time (Čizmar, 2017).

The professional exam for occupational health and safety specialist consists of a general and a special part. The general part of a professional examination can be taken by a person who has at least a gymnasium or a vocational high school degree, and the special part can be taken by a person who has passed the general part of the examination and completed the undergraduate degree obtaining a bachelor's qualification (baccalaureus) (Article 11, paragraphs 1, 3 and 4 of the Ordinance on Occupational Health and Safety Training and Professional Examination).

Professional exams for occupational health and safety specialists are taken in the manner and according to the Ordinance on Occupational Health and Safety Training and Professional Examination. The candidate submits application for taking the exam to the competent ministry (Ministry of Labor and Pension System), and annexed to the Ordinance is the description of all elements that the professional examination for occupational health and safety specialists consists of (http://uznr.mrms.hr; Article 11, paragraph 2, Article 12, paragraph 1 of the Ordinance on Occupational Health and Safety Training and the Professional Examination).

The status of occupational health and safety specialist (general and special part) is awarded to a person who has completed at least the undergraduate degree with a bachelor's qualification and passed a state professional occupational health and safety exam with state administration bodies responsible for occupational health and safety or completed the minimum undergraduate study with the acquired bachelor's degree and passed a state professional examination for labor inspector in the field of occupational health safety (Article 11, paragraph 5 of the Ordinance on Occupational Health and Safety Training and the Professional Examination).

10 In addition, if an authorized person fulfils this requirement, other occupational health and safety specialists may also be employed, and they may be employed full-time or part-time or may contract additional work (up to 8 hours per week in accordance with Article 61 paragraph 3 of the Labor Act (OG, No. 93/14, 127/17, 98/19) (Čizmar, 2017). 


\section{2.3 Conditions for the employer (or his authorized officer) for independent performance of occupational health and safety tasks}

An employer employing up to and including 49 workers can perform occupational health and safety tasks independently or through an authorized person if prescribed conditions are fulfilled (Article 20, paragraph 2 of The Occupational Health and Safety Act). These conditions are stipulated by the Ordinance on Performance of Occupational Health and Safety Tasks. Employer or his authorized officer can perform the aforementioned tasks in the following cases: if he meets the requirements for the occupational health and safety specialist, I degree, prescribed by the Ordinance; or if he has acquired necessary occupational health and safety knowledge during formal education; or if passed a state professional exam for construction or design work that includes occupational health and safety material; or if he has passed the craftsman examination in the activity that he carries out, including occupational health and safety (Article 4 of the Ordinance on Performance of Occupational Health and Safety Tasks). ${ }^{11}$

However, if the employer or his authorized officer meet some of these conditions, but not the one that would allow them to meet the requirements for occupational health and safety specialists, therefore fulfilling one of the three remaining conditions, they would not be able to take part in the risk assessment or trainings as occupational health and safety specialists. If, on the other hand, the employer (or his authorized officer) fulfils the conditions for the occupational health and safety specialist, I degree, prescribed by the Ordinance, he is simultaneously an occupational health and safety specialist and can participate as an occupational health and safety specialist in preparation of risk assessments and training.

It is prescribed that an occupational health and safety specialist must take part in risk assessment and training, but it is not stipulated where this specialist must be employed. Therefore, a specialist may be employed by an employer to perform occupational health and safety tasks or employed with an authorized person. ${ }^{12}$ For a specialist who is employed with the authorized person, it is not decisive whether he is a specialist thanks to the authorized person or if he is a new, independent occupational health and safety specialist employed with the authorized person (Cizmar, 2017).

\subsubsection{Occupational health and safety tasks under the Occupational Health and Safety Act of the Republic of Croatia}

Occupational health and safety tasks are in particular:

- expert assistance to the employer and his authorized employees, employees and employees' commissioners for occupational health and safety in implementation and improvement of occupational health and safety

11 Authors Lalić and Lise emphasize that such legal definition leads to a degraded role of occupational safety professionals and raise the question why such an employer would spend his resources on hiring, educating or training of an occupational safety specialist when the regulation allows him to perform occupational safety tasks by himself (Lalić, Lise, 2017).

12 When the occupational health and safety specialist is employed by an authorized person for training tasks, he must be a specialist, II degree, in accordance with provisions of Article 3, paragraph 1 of the Ordinance on Occupational Health and Safety Training and Professional Examination. 
- participation in the development of business strategy, operational plans and programmes of the employer's business activities, in the part related to occupational health and safety, as well as participation in the implementation of management methods and techniques for strategy implementation

- participation in the procedure of drafting risk assessment

- internal supervision of implementation of occupational health and safety rules, as well as encouragement and consultation for the employer and his authorized officers in eliminating deficiencies in occupational health and safety discovered by the internal control

- collecting and analysing data in relation to work related accidents andinjuries, , occupational diseases and diseases in relation to work as well as preparation of prescribed registration of injuries at work and occupational diseases and drafting reports for the employer's needs

- cooperation with work inspection bodies, with the institute in charge of health protection and safety at work, authorized persons and with a specialist in occupational medicine

- training of employees, employers and authorized officers for work in a safe manner

- training of employees' occupational health and safety commissioners and assistance in their activities

- active participation in the employer's committee for occupational health and safety

- cooperation with the employer during design, construction, and reconstruction of buildings intended for work, procurement of work equipment and other means of work, personal protective equipment, and dangerous chemicals

- participation in implementation of international certification standards for occupational health and safety management, quality, risks, social responsibility in business activities etc. in the undertaking

- other occupational health and safety tasks in accordance with the employer's needs (Article 21, paragraph 1 of The Occupational Health and Safety Act).

Performing these occupational health and safety tasks can be arranged by the employer in the ways outlined in Article 20 of the Act, which are previously presented in this paperwork (under subsection 3.1). Regardless of which of these methods the employer has chosen (independently performing those tasks by fulfilling relevant conditions and competencies, hiring an occupational health and safety specialist or engaging an external service), tasks that must be performed are always at least the ones mentioned in Article 21, paragraph 1 of the Act (Šokčević, 2014).

\section{3 Portuguese legislation}

The Occupational Health and Safety act is the basic act which regulates the area of health and safety at work in Portugal. It regulates issues and relationships among many subjects in occupational safety (L n. ${ }^{\circ} 102 / 2009$, changed by $L$ n. ${ }^{\circ}$ 42/2012, L n. ${ }^{\circ}$ 3/2014, DL n. ${ }^{\circ} 88 / 2015$, L n. ${ }^{\circ}$ 146/2015 and Ln. $\left.{ }^{\circ} 28 / 2016\right)$. 
As in Croatian legislation, the most important roles in Portuguese legislation are given to the employer and the worker or self-employed worker, but their rights, obligations, and responsibilities are also related to other individuals, such as the workers' representative, occupational physician, superior occupational health and safety technician and others. Each of these subjects has the right, obligations and responsibilities, not only under the Occupational Safety Issues, but also according to standards of numerous other heteronomous and autonomous regulations in the field of occupational safety. Certain subjects relevant to the work of some of these entities are regulated by subordinate legal acts.

The occupational health and safety concepts in Article 15 define 11 general obligations of the employer. Until 2016, 9 obligations were defined, but with the changes done in 2016, the number of obligations increased to 11 (Marecos, 2016).

Development of policies and programmes, such as the implementation of pro-active measures, must be supported by coordination of the means available, assessment of results in terms of reducing occupational risks and damage to workers' health, and mobilisation of the actors on whom their implementation depends, particularly the employer, the workers and their representatives (Rebelo, 2019).

The workers' representative is an employee elected to represent the interests of employees in the field of occupational health and safety (Article 4, d of L 102/2009). This representative protects the interests of employees in terms of occupational health and safety and monitors the implementation of rules, measures, procedures, and activities relating to occupational health and safety.

Workers' representatives may submit their comments to the working conditions authority or to another competent authority. They may also request the intervention of the Working Conditions Authority if they find that the measures taken, and the means provided by the employer, are insufficient to ensure health and safety at work.

Superior occupational safety technician is the person that organises, develops, coordinates and controls occupational risk prevention activities, while an occupational safety technician is the person who carries out prevention and protection activities against occupational risks.

\subsection{Performance of occupational health and safety tasks}

Article 100 of The Occupational Health and Safety Law of Portugal, in accordance with Article 7 of the Directive, stipulates the conditions under which the employer undertakes to carry out occupational safety tasks with one or more persons, i.e. an internal or an external service. The number of superior occupational safety technicians and occupational safety technicians depends on the activity and the number of employees.

According to the Occupational Health and Safety Act, contracting the performance of occupational health and safety tasks is based on the number of employees in an industrial company: 
- up to 50 employees, one occupational safety technician, and, over 50, two occupational safety technicians, per 1500 workers covered or fraction, at least one of whom must be a superior occupational safety technician.

In other kinds of establishments:

- up to 50 employees, one occupational safety technician, and, over 50, two occupational safety technicians, per 3000 workers covered or fraction, at least one of whom must be a superior occupational safety technician.

An occupational safety technician is a person who has completed a high school level of education at minimum and possesses the certificate of occupational safety at work approved by the working conditions authority. A superior occupational safety technician is a person who has at minimum completed the undergraduate degree with a bachelor's qualification and possesses the certificate of advanced occupational safety at work approved by the working conditions authority, or possesses the certificate of Master or PhD in the field of occupational safety at work approved by the education authority (Article 5 of the L 42/2012).

\section{3.2 Occupational health and safety deontological principles under the Occupational Health and Safety Act of Portugal}

Occupational health and safety deontological principles:

- to consider the safety and health of workers as priority factors in intervention

- to base activity on scientific knowledge and technical competence and to propose the intervention of specialized experts where necessary

- to acquire and update skills and knowledge necessary for the performance of duties

- to carry out functions with technical autonomy, collaborating with the employer in fulfilling their obligations

- to inform the employer, the workers and their representatives for occupational safety and health about the existence of particularly dangerous situations that require immediate intervention

- to collaborate with workers and their representatives on occupational safety and health by developing their capacity for intervention on occupational risk factors and appropriate prevention measures

- to keep classified information about the organization, methods of production or business of which they are aware by virtue of the performance of their functions

- to protect the confidentiality of data that affects the privacy of workers

- to consult and cooperate with National Network for Prevention of Occupational Risks (Freitas, 2019) 


\section{RESULTS AND DISCUSSION}

Considering the legal provisions of Croatian and Portuguese law related to the provisions of Article 7 of Directive 89/391 / EEC, Croatia and Portugal, as Member States, implemented in their laws and regulations the minimum standards imposed by that Directive. It is also apparent that there are some differences, which is not surprising, since Directive 89/391/ EEC provides the basic rules and obligations of the employer to determine one or more workers to be responsible for the activities related to protection and prevention of occupational risks for the undertaking and/ or establishment or, if that is not possible, stipulate the obligations of the employer to engage professional external services and persons and impose that those workers or services possess the necessary capabilities and resources, while leaving the rest of specific rules and conditions to the Member States.

In this respect, Member States independently determine the required number of workers and their required competences and skills, which applies equally to external services, but they must make sure that the number of appointed workers and external services is sufficient to organize protection and prevention measures depending on the size of undertaking, the dangers to which workers are exposed, and their schedule in the undertaking or establishment.

Differences between Croatian and Portuguese legislation are contained in precisely these provisions. Croatian legislation imposes a different number of such appointees, or services, depending on the number of workers, without distinguishing between an industrial enterprise and other types of establishments, a difference which is contained in Portuguese legislation. However, indirectly, Croatian legislation, through subordinate regulations, makes this distinction in a certain way, focusing on the number of workers in companies where the low-risk jobs are performed most. Furthermore, differences are also reflected in the number of appointed workers compared to the number of employees, but there are no major discrepancies.

One of the more interesting and important differences, especially from the point of view of Croatian occupational safety specialist, is that Portuguese legislation recognizes the person possessing the bachelor certificate, and training recognized by the authority for working conditions, a Master or a PhD certificate in the field of occupational safety at work approved by the Education Authority as an occupational health and safety specialist, II degree. In Croatian law, this is not possible, so even a person who has completed a specialist graduate professional study in occupational safety and education for a total of 5 years in the field of occupational safety and health has to take an additional exam for an occupational safety expert (first and second degree) in order to (subject to other additional conditions) be able to perform occupational safety work with an employer or an authorized person.

Occupational safety and health principles, which occupational safety legislation is based on in both states, equally emphasize occupational safety specialist as a person who provides expert assistance to the employer in the field of occupational safety and health, monitors and supervises the state of occupational safety and health, takes all necessary measures to alert the employer and workers of risks in the work environment, but also to train them to take preventive measures to avoid occupational risks at work. 


\section{CONCLUSION}

As Member States, Croatia and Portugal have implemented the requirements set by Directive 89/391/EEC. The Directive sets only minimum conditions which the Member States must meet, without imposing in any way the obligation to take additional measures if need arises in certain economies, that is, the Member States. Croatian and Portuguese legislations have applied only minimum conditions that vary only minimally. It is evident from the aforementioned that there is not enough will for states to upgrade the minimum conditions required by the directive, which is precisely what the needs and situations in practice require. Therefore, the question arises to whom this situation suits the most, and whether the national legislations of those states try to facilitate and unburden employers at the expense of the profession and, ultimately, of the workers.

It is also concluded that the Directive and legislations under review are not entirely clear with regards to the occupational safety professional, i.e. his competence to perform occupational safety and health activities. It is interesting and somewhat incredible that engineers with a master's degree are not taken into consideration, and in the worst case, not mentioned at all in the legislation of the Republic of Croatia, while the Portuguese legislation recognizes them. This rises the question of competences that persons performing occupational health and safety tasks have when they have only passed a professional examination based solely on legal regulations in contrast to competences and knowledge of specialists with five years of university education in the field. It is evident that states favour and facilitate employers' jobs and thus automatically engage in discrimination against the profession and the workers who are entitled to safe jobs.

Further research should be done towards examining the ability and competence of persons to perform occupational health and safety work, especially regarding occupational health professionals and occupational safety engineers with a Master's degree. Research should also be carried out on the extent to which the legal frameworks of individual states contribute to occupational safety and health protection.

The domain of occupational safety is an interdisciplinary field that cannot be viewed from one position alone: all relevant factors must be taken into account and should not be conducive to any interest group. Safety of the workplace and the workers must be put first because serious injuries and fatalities such as aircraft crashes do not happen often, but when they do, the consequences are disastrous.

\section{REFERENCES}

Bosio, D. et al. (2018), "Emerging needs in OSH: A new master in Occupational Safety and Health by ILO and University of Turin", Sigurnost 60 (4), pp. 321 - 333. https://hrcak.srce.hr/214663 (24. 1. 2020)

Council Directive of 12 June 1989 on the introduction of measures to encourage improvements in the safety and health protection of employees at work (89/391/EEC), OJ L 183, 29. 6. 1989.

Čizmar, Đ. (2017) “Poslovi zaštite na radu prema Zakonu o zaštiti na radu”, Sigurnost, 59 (2), pp. 153-155. https://hrcak. srce.hr/184933 (16. 8. 2019)

Freitas, L. (2019) “Manual de Segurança e Saúde do Trabalho”. Sílabo. 4th ed. Lisbon 
Krišto, I., Batak, M. (2012) “ Istraživanje područja interesa i problema u radu stručnjaka zaštite na radu”, Sigurnost, 54 (3), pp. 303-308. https://hrcak.srce.hr/87366 (24. 1. 2020.)

Labor Act (OG No. 93/14., 127/17., 98/19.)

Lalić, Ž., Lise, I. (2017) "Degradiran položaj stručnjaka zaštite na radu u skladu s novim Zakonom o zaštiti na radu", Sigurnost 59 (3), pp. 237-244. https://hrcak.srce.hr/187220 (25. 1. 2020.)

Marecos, D. (2016) “Lei 102/2009 - Regime Jurídico da Promoção da Segurança e Saúde no Trabalho”. Petrony. Lisbon.

Ministarstvo rada i mirovinskog sustava, Stručnjaci zaštite na radu, http://uznr.mrms.hr/znr/strucnjaci-zastite-na-radu/ (30. 8. 2019.)

Ninčević, A., Pavlič, M. (2016) “Motiviranost stručnjaka zaštite na radu za obrazovanje”, Sigurnost 58 (1), pp. 31-45. https://hrcak.srce.hr/167680 (24. 1. 2020.)

Occupational Health and Safety Act ( $\mathrm{L}$ n. ${ }^{\circ}$ 102/2009, changed by L n. ${ }^{\circ} 42 / 2012, \mathrm{~L}$ n. $3 / 2014$, DL n. $88 / 2015$, L n. ${ }^{\circ}$ 146/2015 and $L$ n. ${ }^{\circ} 28 / 2016$ )

Occupational Health and Safety act (OG No. 71/14., 118/14., 154/14., 94/18., 96/18.)

Ordinance on Authorizations for Occupational Health and Safety tasks (OG No. 50/19.)

Ordinance on Occupational Health and Safety Training and Professional Examination (OG No. 112/14.).

Ordinance on Performing of Occupational Health and Safety Tasks (OG No. 112/14., 43/15., 72/15. i 140/15.)

Rebelo, G. (2019) “Código do Trabalho”. Sílabo, 8th ed. Lisbon

Šarić, V. et al. (2019) "Suradnja kao temelj za promicanje sustava sigurnosti i zdravlja zaposlenika”, Sigurnost, 61 (4), pp. 373-378. https://hrcak.srce.hr/230928 (23. 1. 2020.)

Šokčević, S. (2014) Zakon o zaštiti na radu s komentarima i tumačenjima, Zagreb: TIM press d.o.o.

Treaty on European Union (consolidated version), OJ C 202, 7.6.2016., http://data.europa.eu/eli/treaty/teu_2016/201905-01, 12. 9. 2019.

Učur, M. Đ. (2015) “Neki posebni subjekti i odnosi po Zakonu o zaštiti na radu”, Zbornik Pravnog fakulteta Sveučilišta u Rijeci, 36 (1), pp. 533-546. https://hrcak.srce.hr/141262 (20. 7. 2019.)

Učur, M. Đ. (2013) “Promišljanje prava zaštite na radu kao samostalne pravne discipline”, Zbornik Veleučilišta u Rijeci, 1 (1), pp. 197-208. https://hrcak.srce.hr/103333 (24. 1. 2020.)

Vedenik, L. (2011) "Sigurnost i zaštita zdravlja na radu kao sastavni dio nacionalne i državne sigurnosti”, Sigurnost 53 (3), pp. 235-242. https://hrcak.srce.hr/71904 (24. 1. 2020.) 


\title{
STRUČNJAK ZAŠTITE NA RADU U HRVATSKOM I PORTUGALSKOM ZAKONODAVSTVU
}

\author{
Domagoj Šantek \\ Struč. spec. ing. sec., diplomirani student, Veleučilište u Rijeci, Vukovarska 58, 51000 Rijeka, Hrvatska; \\ e-mail:dsantek5@gmail.com \\ Sandra Debeljak \\ Dr. sc., predavač, Veleučilište u Rijeci, Vukovarska 58, 51000 Rijeka, Hrvatska; \\ e-mail: sandra.debeljak @veleri.hr

\section{Rui Isidoro} \\ Dr. sc., prof. v. š., Polytechnic Institute of Beja, Rua Pedro Soares, \\ Campus do Instituto Politécnico de Beja, 7800-295 Beja, Portugal: e-mail: rui.isidoro@ipbeja.pt
}

\section{SAŽETAK}

Osnivačkim ugovorima određeno je da se područje sigurnosti i zaštite zdravlja na radu uređuje putem direktiva. To znači da institucije Europske unije putem direktiva propisuju minimalne standarde sigurnosti izaštite na radu, a države članice obvezne su ostvariti ciljeve koje pojedina direktiva postavlja. Istovremeno to znači da svaka država članica može propisati i strože standarde od onih propisanih direktivama pa se iz tog razloga mogu uočiti i određene razlike u propisima pojedinih država članica. Autori se u radu usmjeravaju na ulogu stručnjaka zaštite na radu i način na koji Hrvatska i Portugal u svojem zakonodavstvu propisuju obveze poslodavca u pogledu ugovaranja poslova zaštite na radu sa stručnjakom zaštite na radu ili vanjskom službom. Nadalje, autori ispituju uvjete koje mora ispunjavati stručnjak zaštite na radu za obavljanje svojih poslova. Uz prikaz hrvatskog i portugalskog zakonodavstva, autori definiraju i prikazuju i temeljne sličnosti i razlike u propisima unutar ovog područja zakonodaustva sigurnosti.

Ključne riječi: Direktiva 89/391/EEZ, stručnjak zaštite na radu, hrvatsko zakonodavstvo, portugalsko zakonodaustvo 

TEHNIČKE ZNANOSTI 
